\title{
The use of FTIR and Raman spectroscopy in combination with chemometrics for analysis of biomolecules in biomedical fluids:
} \section{A review}

\author{
Abdul Rohman $^{\mathrm{a}, \mathrm{b}, *}$, Anjar Windarsih ${ }^{\mathrm{c}}$, Endang Lukitaningsih ${ }^{\mathrm{a}}$, Mohamad Rafi $^{\mathrm{d}}, \mathrm{K}_{\text {. Betania }}{ }^{\mathrm{e}}$ \\ and Nurrulhidayah A. Fadzillah ${ }^{\mathrm{e}}$

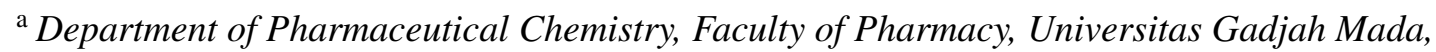 \\ Yogyakarta 55281, Indonesia \\ ${ }^{\mathrm{b}}$ Institute of Halal Industry and Systems (IHIS), Universitas Gadjah Mada, Yogyakarta 55281, \\ Indonesia \\ ${ }^{\mathrm{c}}$ Research Division for Natural Product Technology (BPTBA), Indonesian Institute of Sciences (LIPI), \\ Yogyakarta, 55861, Indonesia \\ ${ }^{\mathrm{d}}$ Department of Chemistry, Faculty of Mathematics and Natural Sciences, IPB University, Jalan \\ Tanjung Kampus IPB Dramaga, Bogor 16680, Indonesia \\ ${ }^{\mathrm{e}}$ International Institute for Halal Research and Training, International Islamic University Malaysia, \\ Gombak, Selangor, 53000, Malaysia
}

\begin{abstract}
Fourier transform infrared (FTIR) and Raman spectroscopy are complementary techniques, typically called vibrational spectroscopy. Both techniques allow simple, rapid, non-destructive, specific, providing fingerprint spectra, and real-time analytical method for analysis of molecules in different states. Besides, these methods are simple without any excessive sample pre-treatment, therefore, they are sometimes called as "green analytical methods". Biofluids have several biomolecules such as lipid, protein, nucleic acids, and carbohydrates. These biomolecules can be used as biomarkers to detect some types of diseases, since biomolecules are in direct contact with the human organs. FTIR and Raman spectra of biofluids are complex in nature, therefore sophisticated statistical techniques, known as chemometrics, must be used to solve the analytical problems related to quantitative analysis purposes. The objective of this review is to show the capability of FTIR and Raman spectroscopic techniques in combination with chemometrics techniques to analyze the biomolecules in biofluids through an extensive literature review. During performing this review, several databases in Science citation index, Scopus PubMed, and Google Scholar related to the topics are identified and downloaded. With the present review, it is known that FTIR and Raman techniques are rapid method for screening certain diseases by identifying the level changes of some biomolecules. In the future, this method will be widely used for clinicians as new diagnostic tools for many diseases.
\end{abstract}

Keywords: FTIR spectroscopy, Raman spectroscopy, chemometrics, biomolecules, biofluids

\footnotetext{
${ }^{*}$ Corresponding author: Abdul Rohman, Ph.D. Professor in Department of Pharmaceutical Chemistry Faculty of Pharmacy, Gadjah Mada University Yogyakarta, Indonesia. Tel.: +6287838445216; E-mail: abdulkimfar@ gmail.com.
} 


\section{Introduction}

Infrared (IR) and Raman spectroscopies are called as vibrational spectroscopy which are commonly used for analysis of different states of samples (solid, liquid, and semi-solid). Vibrational spectroscopy (VS) allows the production of unique fingerprint spectra due to the interaction between electromagnetic radiation (EMR) in infrared regions with biomedical samples to resulting the molecular vibrations $[6$, 43]. VS is used to describe the collective terms of two powerful spectroscopic techniques, namely IR spectroscopy either in near region corresponding to wavenumber $(1 / \lambda)$ of $14,000-4000 \mathrm{~cm}^{-1}$, mid region corresponding to $1 / \lambda$ of $4000-400 \mathrm{~cm}^{-1}$, or far region corresponding to $1 / \lambda 400-50 \mathrm{~cm}^{-1}$, and Raman spectroscopy [44].

Raman and IR are complementary techniques that allow real-time analysis of analytes of interest in biomedical samples with good sensitivity as expressed with relatively low detection limit, since both techniques are non-destructive analytical technique in which the analyzed samples could be analyzed further with other analytical techniques such as chromatographic-based methods [38]. Besides, VS provides highly specific information of target compounds which allow the identification of analytes by a structural and biochemical diversity. Both techniques are also considered as green analytical technique because of its minimal uses of solvents and chemical reagents during analysis, therefore the environment pollution can be hindered [15].

Due to the advancement of instrumentation, Fourier transform infrared (FTIR) and FT-Raman have been introduced and popular over the dispersive instruments. FTIR spectroscopy measures the absorption, reflection, or transmission of EMR in mid-infrared, due to the interaction of the electric dipole moment of the molecule bands with the infrared radiation [12]. FTIR spectrum is a plot of intensity of the absorbed or transmitted light ( $y$-axis) relative to the $1 / \lambda$ ( $x$-axis), a variable proportional to frequency. In addition, FT-Raman spectroscopy employs the inelastic scattering of EMR by samples, which known as Raman scattering. This technique was based on the sample illumination with EMR corresponding to IR region and used to measure the fractions of scattered radiation for which the energy of EMR has changed. FT-Raman spectrum described the correlation between intensity of the scattered light ( $y$-axis) relative to the $1 / \lambda$ of the incident laser excitation ( $x$-axis) [23]. Both FTIR and FT-Raman are known as fingerprint spectroscopic technique because every molecule has unique spectra, which makes both techniques are highly specific for the identification (qualitative analysis) and structural elucidation of molecules. Both techniques provide qualitative and quantitative analyses related to vibrational modes of specific functional groups in analytes and sometimes called as sister or complementary techniques. These techniques are ideal for analytical applications, especially in biomedical applications for analysis of several biomarkers including proteins, lipids, nucleic acids, and carbohydrates, and others $[28,69]$.

\section{Methods}

During performing this review, we explored several databases such as Science Citation index, PubMed, Medline, Scopus, and Google Scholar to identify and to download the abstracts, reports, review articles and research papers related to the vibrational spectroscopy (FTIR and Raman) and its application in quantitative analysis of biomolecules in the biofluids. The keywords used during searching of information were: FTIR spectroscopy or Raman spectroscopy + chemometrics + biomolecules (lipid, protein, nucleic acid and carbohydrates). 


\section{Analysis of biomolecules in biofluids}

Biofluids have several biomolecules which can be used as biomarkers to detect some types of diseases, since these biomolecules are in direct contact with the human organs [27,34]. The other advantage of biofluids as matrix samples is its availability and ease to get blood and urine for repeated testing. Biofluids are also potential to be used in monitoring the progression of diseases or treatment [4]. With this in mind, the level changes of biomolecules in biofluids can provide substantial amount of information about patient diseases in order to improve the clinical analysis. Maes et al. [42] reported that there is a relationship between the changes of lipid levels in the membranes of red blood cells with the severity of affective disorders. Other studies also reported that depression correlated with the increased concentration of the triglycerides and low-density lipoprotein (LDL)-cholesterol. The deficiency of phospholipids is also used as depression marker [2,64]. The measurement of protein concentrations is useful to interpret some biological parameters, discuss the nutritional status, and to help the diagnosis of some diseases. Specific proteins like immunoglobulin $\mathrm{G}$ and human serum albumin may be changed during certain diseases such as inflammation and infection [5]. The changes of nucleic acids are also correlated with certain diseases like cancers [50]. In addition, the levels of carbohydrates were associated with diabetes mellitus [24].

\section{Chemometrics}

FTIR and Raman spectra in biofluids are complex in nature, therefore, the sophisticated statistical technique, known as chemometrics, must be used to solve the analytical problems related to the quantitative analysis purposes. Chemometrics is the application of mathematics and statistics to treat chemical data such as biomolecules in biofluids which help analytical chemists to deal with all steps of analytical procedures, starting from the experimental design and optimization through extraction of chemical information and final decision [14]. Chemometrics allows the simultaneous determination of several independent variables (factors) against several dependent variables or responses [32].

The chemometrics techniques commonly used in FTIR and Raman spectroscopy include (1) spectral processing using derivatization (first and second derivatives), standard normal variate (SNV), multiplicative scattering correction (MSC), filtering, wavelet transformations (WT), feature selection, and folding-unfolding, (2) classification techniques which can be either supervised pattern recognition such as principal component analysis (PCA) or unsupervised pattern recognition such as linear discriminant analysis (LDA), partial least square-discriminant analysis (PLS-DA), and orthogonal projection to latent structures-discriminant analysis (OPLS-DA) and (3) multivariate calibrations used for quantitative analysis of biomolecules such as stepwise multiple linear regression (SMLR), principle component analysis (PCR), partial least square regression (PLSR) and modified PLSR [37,52].

Figure 1 showed the general scheme of chemometrics techniques applied to analysis of biomolecules in biofluid using FTIR and Raman spectra as variables [59]. Some user friendly statistical and chemometrics softwares are available which are either free or commercially available to perform statistical analysis of complex data with its advantages and features. Such softwares are Unscrambler ${ }^{\circledR}$, SIMCA $^{\circledR}$ SIRIUS ${ }^{\circledR}$, and Pirouette ${ }^{\circledR}$ offering standard methods of multivariate statistical analysis including chemometrics classification (PCA and SIMCA) as well as multivariate calibrations (PCR, PLS, SMLR). The softwares of Minitab ${ }^{\circledR}$ Matlab $^{\circledR}$ are routinely designed to facilitate the writing of personal programs, while Grams ${ }^{\circledR} 32$ is particularly useful for calibration modelling during quantitative analysis rather than for the exploration of a data matrix and classification by different pattern recognition techniques [46,51]. 


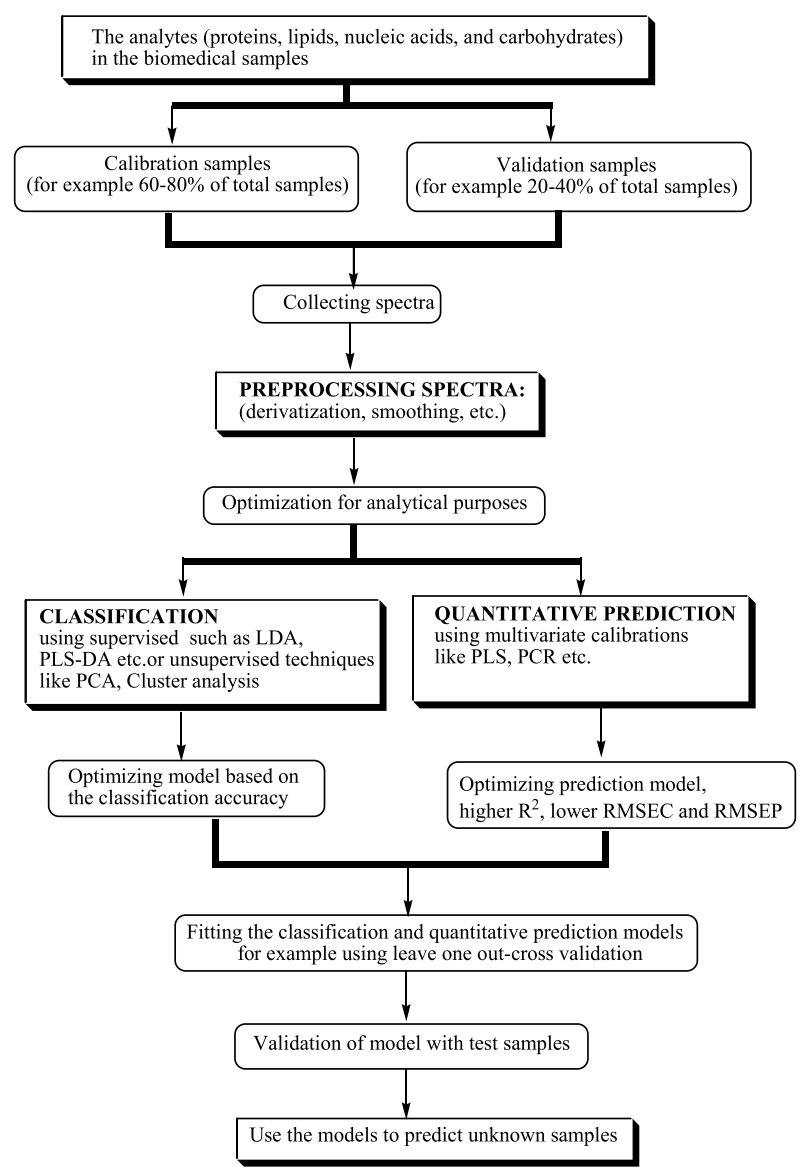

Fig. 1. The general steps during the application of vibrational spectroscopy (FTIR and Raman spectroscopy) combined with chemometrics for analysis of biomolecules such as proteins, lipids and nucleic acids in biofluids (adapted from depciuch and parlinska-wojtan [16]). LDA = linear discriminant analysis; PLS-DA = partial least square-discriminant analysis; $P C A=$ principal component analysis; $P L S=$ partial least square; $P C R=$ principle component regression; $R^{2}=$ coefficient of determination; $R M S E C=$ root mean square error of calibration; $R M S E P=$ root mean square error of prediction.

\section{Application of FTIR spectroscopy combined with chemometrics for analysis of analytes in biomedical fluids}

The combination of FTIR spectroscopy and rapid sampling technique such as attenuated total reflectance (ATR) has accelerated the application of this method. ATR-FTIR spectroscopy has been reported to be suitable technique for analysis of analytes in biomedical materials, including serum. Currently, FTIR spectroscopy, combined with multivariate calibrations, are popular to be applied in quantitative analysis in biomedical analysis because they obey the principles of the Beer-Lambert law in which the absorbance of certain functional groups are proportional with concentrations of analytes $[43,62]$. This enables ATR-FTIR spectroscopy to quantify specific biomolecule concentrations, as the proportion of light absorbed by the sample will correlate with the concentration of molecules within a sample. Table 1 provided the use of FTIR spectroscopy for analysis of biomolecules (proteins, lipids, nucleic acids and carbohydrates) in the biomedical samples. The use of FTIR spectroscopy combined with certain chemometrics allows the direct measurement of chemical constituents in biomedical matrices without 
Table 1

The application of FTIR spectroscopy combined with chemometrics for analysis of biomolecules in biological fluids

\begin{tabular}{|c|c|c|c|c|c|}
\hline Samples & Analytes & FTIR condition & Chemometrics & Remarks & References \\
\hline Serum & Glucose & $\begin{array}{l}\text { Combined regions of } \\
988-1440 \mathrm{~cm}^{-1} \text { and } \\
2620-3060 \mathrm{~cm}^{-}\end{array}$ & PLSR & $\begin{array}{l}Y=0.89 x+0.45 \text { with } R^{2} \\
\text { of } 0.994 \text { Standard error: } \\
0.29 \mathrm{mmol} / \mathrm{L} \text { LOD: } 0.55 \\
\mathrm{mmol} / \mathrm{L}\end{array}$ & $\begin{array}{l}\text { Jessen et al. } \\
{[33]}\end{array}$ \\
\hline Serum & Glucose & $\begin{array}{l}\text { Wavenumber of } \\
1600-900 \mathrm{~cm}^{-1}\end{array}$ & PLSR & $\begin{array}{l}R^{2} \text { calibration }=0.896 \\
\mathrm{RMSEC}=0.918 \\
R^{2}=0.882 ; \mathrm{RMSEP}= \\
0.831\end{array}$ & Xie et al. [68] \\
\hline Serum & $\begin{array}{l}\text { Protein (albumin, } \\
\text { immunoglobulin, } \\
\text { total globulin, and } \\
\text { albumin/globulin } \\
\text { coefficients }\end{array}$ & $\begin{array}{l}\text { Wavenumber of } \\
4000-600 \mathrm{~cm}^{-1}\end{array}$ & PLSR & $\begin{array}{l}R^{2}=0.932,0.850,0.886 \\
\text { and } 0.900 \text { for albumin, } \\
\gamma \text {-globulin, total globulin } \\
\text { and albumin/globulin } \\
\text { RMSEC }= \\
0.087-0.136 \mathrm{~g} / \mathrm{dL} \\
\text { RMSEP }= \\
0.093-0.191 \mathrm{~g} / \mathrm{dL} \\
\text { RMSECV }= \\
0.095-0.149 \mathrm{~g} / \mathrm{dL}\end{array}$ & $\begin{array}{l}\text { Perez-Guaita } \\
\text { et al. [49] }\end{array}$ \\
\hline Serum & $\begin{array}{l}\text { Protein (Albumin, } \\
\text { IgG) }\end{array}$ & Regions of $1800-900 \mathrm{~cm}^{-1}$ & PLSR & $\begin{array}{l}\text { Albumin: } R^{2}=0.989 \\
\text { RMSECV }=2.347 \text { IgG: } \\
R^{2}=0.998 ; \text { RMSECV }= \\
0.487\end{array}$ & $\begin{array}{l}\text { Spalding et } \\
\text { al. [61] }\end{array}$ \\
\hline Serum & $\begin{array}{l}\text { Lipids, } \\
\text { chylomicron-TG and } \\
\text { VLDL-TG }\end{array}$ & $\begin{array}{l}\text { Combined regions of } \\
900-1160,1350-1480, \\
1715-1765, \\
2830-2950 \mathrm{~cm}^{-1} \\
(\text { chylomicron-TG); and } \\
910-1170,1350-1480, \\
1715-1765, \\
2840-3000 \mathrm{~cm}^{-1} \\
(\text { VLDL-TG) }\end{array}$ & PLSR & $\begin{array}{l}\text { The correlation between } \\
\text { actual values of as } \\
\text { determined by conventional } \\
\text { enzymatic assay ( } x \text {-axis) } \\
\text { and FTIR predicted } \\
(y \text {-axis): } Y=0.9 x+2.8 \\
\left(R^{2} \text { of } 0.99\right) \text { for } \\
\text { chylomicron-TG } \\
Y=0.999 x+5.8\left(R^{2} \text { of }\right. \\
0.96) \text { for VLDL-TG }\end{array}$ & $\begin{array}{l}\text { Sato et al. } \\
{[56]}\end{array}$ \\
\hline Serum & $\begin{array}{l}\text { Lipids (LDL and } \\
\text { LDL) }\end{array}$ & 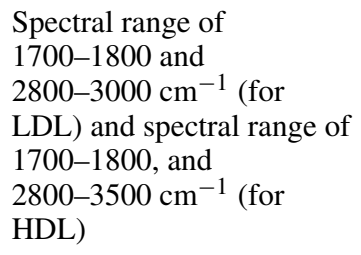 & PLSR & $\begin{array}{l}\text { For LDL, } R^{2}=0.98 \\
\text { RMSEC }=0.34 \\
Y=0.90 x+0.30 \text { For } \\
\text { HDL, } R^{2}=0.91 \\
\text { RMSEC }=0.26 \\
Y=1.0 x+0.01\end{array}$ & Liu et al. [40] \\
\hline Plasma & $\begin{array}{l}\text { Biomarkers (protein, } \\
\text { lipid, nucleic acid) }\end{array}$ & $\begin{array}{l}\text { Spectral range of } \\
1800-900 \mathrm{~cm}^{-1} \text {; baseline } \\
\text { correction; normalized to } \\
\text { the Amide I peak }\end{array}$ & $\begin{array}{l}\text { PCA-LDA, } \\
\text { GA-LDA }\end{array}$ & $\begin{array}{l}\text { PCA-LDA and GA-LDA } \\
\text { were successfully detected } \\
\text { ovarian cancer based on } \\
\text { biochemical alterations. }\end{array}$ & $\begin{array}{l}\text { Lima et al. } \\
\text { [39] }\end{array}$ \\
\hline Cell & Nucleic acid (DNA) & $\begin{array}{l}\text { Wavenumber of } \\
4000-400 \mathrm{~cm}^{-1}\end{array}$ & PCA & $\begin{array}{l}\text { Samples from normal } \\
\text { patients and cancer patients } \\
\text { were clearly separated }\end{array}$ & $\begin{array}{l}\text { Gok et al. } \\
\text { [29] }\end{array}$ \\
\hline
\end{tabular}

$P L S R=$ partial least square regression $; P C A=$ principal component analysis; $P C A-L D A=$ principal component analysislinear discriminant analysis; GA-LDA = genetic algorithm-linear discriminant analysis.

the use of specific reagents. This could be a step forward for the simplification of analytical steps in clinical laboratories. Problems related to the analytical procedure such as improper handling and lot-to-lot variations could be eliminated by direct measurement $[49,57]$. 


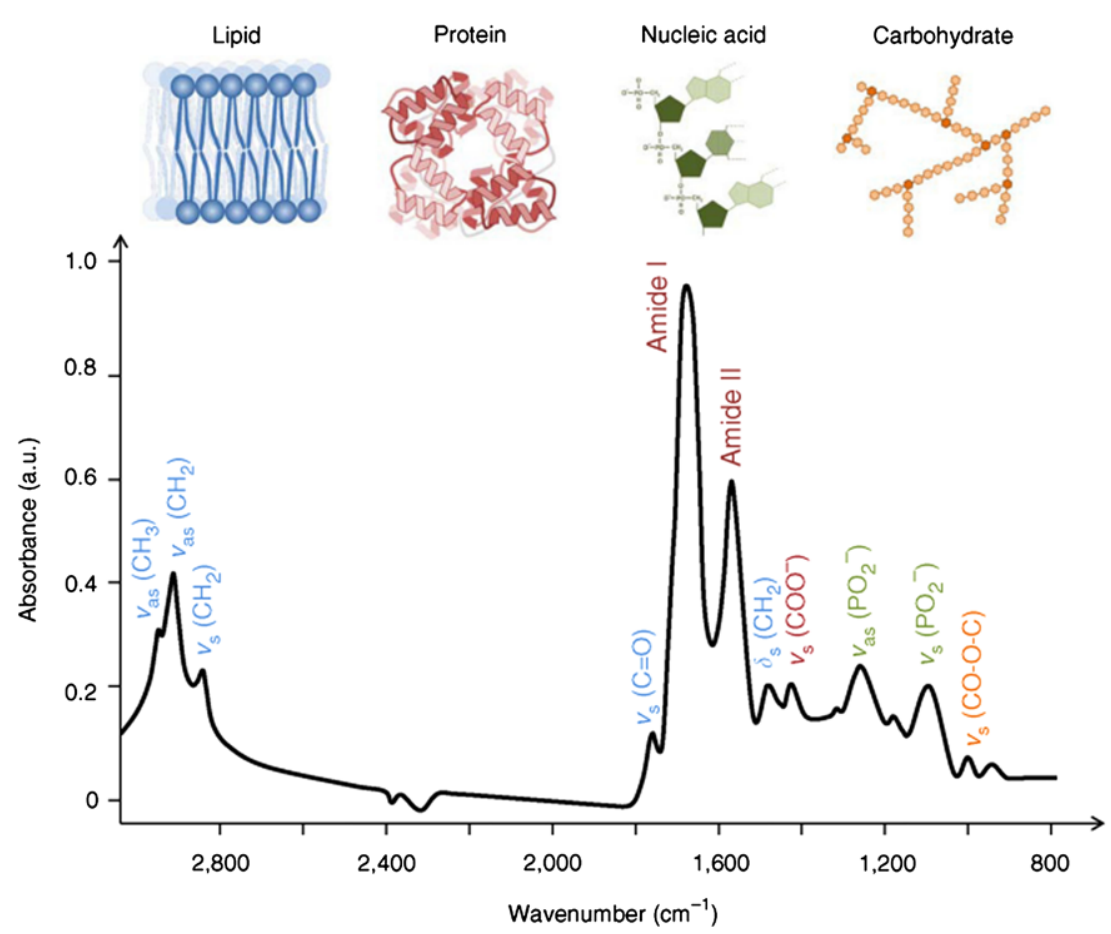

Fig. 2. Typical FTIR spectra of biomolecules in biofluids at wavenumber of $3.000-800 \mathrm{~cm}^{-1}$, along with corresponding functional groups. $v=$ stretching vibrations, $\delta=$ bending vibrations, $\mathrm{s}=$ symmetric vibrations and as $=$ asymmetric vibrations. Adapted from Baker et al. [7].

Figure 2 revealed the functional groups responsible for IR absorption for the specific biomolecules in biomedical fluids especially proteins, lipids, nucleic acids and carbohydrates. The amide groups correspond to $1 / \lambda$ region of amide I and amide II $\left(1500-1700 \mathrm{~cm}^{-1}\right)$ which are specific in proteins and nucleic acids [8]. Specifically, the amide bands can be characterized by the presence of absorption peaks at $1648 \mathrm{~cm}^{-1}, 1544 \mathrm{~cm}^{-1}$, and $1314 \mathrm{~cm}^{-1}$ for amide I, amide II, and amide III, respectively. There are some peak assignments related to protein structures based on the assignment of Amide I band. Generally, the structure of $\alpha$-helic exhibited peak at $1 / \lambda 1650-1658 \mathrm{~cm}^{-1}, \beta$-sheet structures revealed bands at $1 / \lambda$ $1640-1620 \mathrm{~cm}^{-1}$ and $1 / \lambda 1695-1670 \mathrm{~cm}^{-1}$, and peaks of random coil structures at around $1644 \mathrm{~cm}^{-1}$ [63]. In biological fluid containing water, the study of aqueous protein is challenging task due to the overlapping between absorption peak of $-\mathrm{OH}$ in water and bending vibration of amide I at around $1600 \mathrm{~cm}^{-1}$. This problem could be overcome using $\mathrm{D}_{2} \mathrm{O}$, but this can affect the native secondary structure of protein. Fortunately, current FTIR spectrophotometers were equipped with sophisticated software which allow the accurate subtraction of sample peaks with water-related bands $[30,36]$.

FTIR spectra of lipids were characterized by absorption peaks at $2963 \mathrm{~cm}^{-1}, 2922 \mathrm{~cm}^{-1}$ and $2850 \mathrm{~cm}^{-1}$ corresponding to asymmetric stretching vibrations of $\mathrm{CH}_{3}, \mathrm{CH}_{2}$ and symmetric vibration of $\mathrm{CH}_{2}$, respectively. In addition, phospholipid was characterized by absorption peaks at $1 / \lambda 1057$ and $1249 \mathrm{~cm}^{-1}$ [20,31]. Depciuch and Parlinska-Wojtan [16] have compared FTIR spectra of serum from dried and liquid blood serum samples of depressed patients and healthy blood serum. FTIR spectra of two samples (dried versus liquid) exhibited the same vibration patterns of peaks derived from proteins and lipids. But, the intensities of peaks corresponding to proteins and lipids in depressed blood serum are lower than those in healthy blood serum. 


\subsection{Carbohydrate analysis using FTIR spectroscopy}

Jessen et al. [33] have developed FTIR spectroscopy combined with PLSR for quantitative analysis of glucose in serum using combined $1 / \lambda$ region of $988-1440 \mathrm{~cm}^{-1}$ and $2620-3060 \mathrm{~cm}^{-1}$ without any preparation step. FTIR spectra were subjected to the first derivative using the Savitzky-Golay algorithm with 9 smoothing points. The spectra were recorded in absorbance mode and subtracted by water blank spectrum. The actual values of glucose were measured using hexokinase method as described by [54]. The correlation between actual values ( $x$-axis) and FTIR predicted values ( $y$-axis) at concentration range of $2.7-23 \mathrm{mmol} / \mathrm{L}$ yielded the equation of $y=0.89 x+0.45$ with $R^{2}$ of 0.994 . The standard error and limit of detection obtained were $0.29 \mathrm{mmol} / \mathrm{L}$ and $0.55 \mathrm{mmol} / \mathrm{L}$, respectively. The authors concluded that this technique offered reliable and rapid analysis with the total time of whole analysis from sample measurement until data report is about 2-3 min.

\subsection{Qualitative and quantitative analysis of protein}

The changes in protein concentration in human blood can be used as an indicator for the nutritional status and certain illnesses state. ATR-FTIR spectroscopy has been applied to detect the minor difference of protein qualitatively and quantitatively in the biological samples [60]. The human serum samples spiked with proteins of human serum albumin (HSA) and immunoglobulin G (IgG) at seven different concentrations were directly analyzed on crystal ATR and their spectra were used for making prediction and validation models using multivariate calibration of PLSR. The wavenumber $(1 / \lambda)$ of 1640-1560 $\mathrm{cm}^{-1}$, associated with stretching vibration of amide groups, were used for quantitative analysis. This band was increased with the increasing levels of proteins (HSA and IgG). In the sipked samples model, the $R^{2}$ values for the prediction of HSA and IgG were 0.982 and 0.947 , respectively in liquid patient samples. The cross validation model using leave one out technique, root mean square error of cross validation (RMSECV) obtained were relatively low, namely $3.065 \mathrm{mg} / \mathrm{mL}$ and $2.365 \mathrm{mg} / \mathrm{mL}$ respectively for HSA and IgG. This method was succesfully applied for analysis of patient samples with acceptable accuracy and precision. ATR-FTIR spectroscopy was also used for the quantitative analysis of IgA, IgG and IgM in myeloma affected blood samples. Quantitative analysis was performed by investigating the ratio $(R)$ of absorbance values at several wavenumbers $\left(\mathrm{cm}^{-1}\right)$, namely $R_{1}\left(\mathrm{Abs}_{2874 / 2930}\right)$, $\mathrm{R}_{2}\left(\mathrm{Abs}_{1542 / 1654}\right), \mathrm{R}_{3}\left(\mathrm{Abs}_{1315 / 1404}\right), \mathrm{R}_{4}\left(\mathrm{Abs}_{1165 / 1244}\right)$ and $\mathrm{R}_{5}\left(\mathrm{Abs}_{953 / 1025}\right)$. The results showed that these ratios are decreased in myeloma samples than those in normal serum samples [55].

The combination of ATR-FTIR spectra and multivariate calibration of PLSR was succesfully applied for quantification of $\operatorname{IgA}, \operatorname{IgG}, \operatorname{IgM}$ in the plasma samples. The spectra of dried human plasma samples were analyzed at mid IR region (4000 to $500 \mathrm{~cm}^{-1}$ ) at resolution of $2 \mathrm{~cm}^{-1}$ and number of scanning of 32. The $R^{2}$ for the correlation between actual values of IgA, IgG and IgM and FTIR-predicted values were $0.98,0.98$, and 0.97 , respectively. The error in validation model expressed by root mean square error of prediction (RMSEP) was relatively low, namely $0.05 \mathrm{~g} / \mathrm{L}(\operatorname{IgA}), 0.4 \mathrm{~g} / \mathrm{L}(\operatorname{IgG})$, and $0.03 \mathrm{~g} / \mathrm{L}$ $(\operatorname{IgM})$. The relative standard deviation for reproducibility study was less than $2 \%$ for all analytes [9].

The complex nature of biological fluid samples is still the limiting factors for direct analysis using ATR-FTIR spectroscopy. For this reason, some innovations by combining sample preparation step and direct measurement using FTIR spectroscopy has been proposed. Elsohaby et al. [22] have coupled centrifugal ultrafiltration and ATR-FTIR spectroscopy for quantitative analysis of IgA in human serum. The actual values of IgA were determined using reference method of immunoturbidimetric assay. The whole serum samples and residue reconstituted with saline after centrifugal ultrafiltration were subjected 
to FTIR spectral measurement at 4000-650 $\mathrm{cm}^{-1}$. PLSR calibration models using 5 factors (for whole serum) and 9 factors (for the reconstituted residue) was succesfully applied for relating the actual values of IgA and FTIR predicted values. The RMSEP value reported was in the range of 79-102 $\mathrm{mg} / \mathrm{dL}$.

ATR-FTIR at $1 / \lambda$ of $4000-600 \mathrm{~cm}^{-1}$ has been used for determination of proteins (albumin, immunoglobulin, total globulin, and albumin/globulin coefficients) in serum and blood samples. The actual values of proteins were determined using electrophoresis which involved 200 samples in calibration sets and 120 samples in validation sets [48]. Some $1 / \lambda$ region and FTIR spectral processing (normal versus derivative) have been optimized to get the best results in terms of the highest $R^{2}$ value and the lowest root mean square error of calibration (RMSEC) and RMSEP values. The regions related to amide I and amide II bands were used for quantitative analysis, namely albumin at $1 / \lambda 1228-1024 \mathrm{~cm}^{-1}$ using first derivative (1st der) spectra with 6 factors, $\gamma$-globulin at $1 / \lambda 1392-1024 \mathrm{~cm}^{-1}$ using 1 st der spectra with 6 factors, total globulin at $1 / \lambda 1440-1018 \mathrm{~cm}^{-1}$ using $1 \mathrm{st}$ der spectra with 4 factors, and albumin/globulin coefficients using $1 / \lambda 1531-1242 \mathrm{~cm}^{-1}$ using 1 st der spectra and standard normal variate (SNV) with 5 factors. The $R^{2}$ values for the correlation between actual values and FTIR predicted values were 0.932 , $0.850,0.886$ and 0.900 for albumin, $\gamma$-globulin, total globulin and albumin/globulin, respectively. The RMSEC values ranged 0.087-0.136 g/dL, RMSEP values of 0.093-0.191 g/dL. The cross validations resulted RMSECV value of 0.095-0.149 g/dL. This result indicated that FTIR spectroscopy combined with PLS regression could be used to predict proteins in serum samples.

\subsection{Quantitative analysis of lipids}

ATR-FTIR spectra have been applied for rapid analysis of very low density lipoprotein-triglyceride (VLDL-TG) serum in maternal serum without any sample preparation. The multivariate calibration of PLS was applied for prediction the levels of VLDL-TG. Using second derivative FTIR spectra at combined $1 / \lambda$ region of $3100-2800$ and $1800-1000 \mathrm{~cm}^{-1}$ with 3 PLS factors, the correlation between actual values ( $x$-axis) of VLDL-TG as determined by Triglyceride GPO-PAP spectrophotometric assay (Roche Diagnostics) and FTIR predicted values ( $y$-axis) was $y=0.985 x+0.784$ with $R^{2}$ value of 0.985 . The calibrated model was validated using independent samples to yield $R^{2}$ value of 0.890 and RMSEP of $0.20 \mathrm{~mol} / \mathrm{L}$. This method has been successfully applied in serum and in ultracentrifugated VLDL fractions from 32 patients with acceptable accuracy and precision. Quantitative analysis of VLDL-TG by FTIR spectroscopy seems to be promising screening technique to identify women with increased risk of adverse pregnancy outcomes [47].

The presence of triglycerides (TG) in serum was analyzed using FTIR spectroscopy and multivariate calibration of PLSR. FTIR spectra were subjected to mean centering and first derivatization. The combined $1 / \lambda$ regions of $1117-1200,1429-1483,1700-1785,2780-3060 \mathrm{~cm}^{-1}$ was used to predict the levels of TG without any preparation step. The correlation between actual values of TG as determined using enzymatic colorimetry ( $x$-axis) according to Wahlefeld [65] and FTIR predicted values ( $y$-axis) resulted an equation of $y=0.73 x+0.15$ with $R^{2}$ of 0.989 , standard deviation of response of 0.035 $\mathrm{mmol} / \mathrm{L}$ and limit of detection of below $0.34 \mathrm{mmol} / \mathrm{L}$.

\subsection{Analysis of nucleic acids in biomedical fuids}

Quantification of DNA in eukaryotic cells has been performed using FTIR spectroscopy method in combination with chemometrics of PLS regression. DNA quantification was performed using standard consisting of DNA and hemoglobin standards. PLS model was built at the fingerprint region of FTIR 
spectra (1800-850 $\left.\mathrm{cm}^{-1}\right)$. The model was evaluated using $R^{2}$ values. The peaks of DNA were observed at $1225 \mathrm{~cm}^{-1}$ (asymmetric phosphate stretching), $1087 \mathrm{~cm}^{-1}$ (symmetric phosphate stretching), $1051 \mathrm{~cm}^{-1}$ (C-O-C stretching), $970 \mathrm{~cm}^{-1}$ (C-C stretching), and $1715 \mathrm{~cm}^{-1}$ (C=O stretching). PLS was performed either in dehydrated or hydrated models. The $R^{2}$ values were higher than 0.96 for all build models with lower RMSEP. It indicated that the PLS model has good accuracy, good predictivity, and good of fitness for DNA quantification [67].

FTIR spectroscopy has been used for analysis of nucleic acid in bladder cancer subject. FTIR measurement was performed at mid infrared region $\left(4000-400 \mathrm{~cm}^{-1}\right)$ using resolution of 4 at 100 scans number. The peak of $\mathrm{PO}_{2}{ }^{-}$stretching vibration in nucleic acid appeared specific at $1086 \mathrm{~cm}^{-1}$ measured using FTIR spectrophotometer. In the condition of bladder cancer, the peak shifted to around $1087 \pm$ $0.87 \mathrm{~cm}^{-1}$ compared to control. Some vibrations especially stretching vibration was increased significantly in cancer subject compared to control. The peak appeared at $967 \mathrm{~cm}^{-1}$ could be considered as marker peak to detect tumors. FTIR measurement of sample from bladder cancer subjects showed slight shifting from $967.22 \pm 0.33 \mathrm{~cm}^{-1}$ to $967.40 \pm 0.31 \mathrm{~cm}^{-1}$. Moreover, the peak at $1 / \lambda 930 \mathrm{~cm}^{-1}$ in bladder cancer appeared at higher intensity than in control. The shifting of FTIR spectra is associated with considerable changes of nucleic acid (DNA) in the case of cancer because of uncontrolled cell proliferation, uncontrolled cell growth, and decreasing of nucleid acid stability. The use of chemometrics principal component analysis was also successfully differentiate between samples from normal and bladder cancer subjects [29].

\section{Application of Raman spectroscopy for analysis of biomolecules in biomedical fluids}

There are several variants of FT-Raman spectroscopy applying the phenomenon of Raman scattering in different ways which included Conventional Raman Spectroscopy (CRS), Surface-enhanced Raman Spectroscopy (SERS), Resonance Raman Spectroscopy (RRS), coherent anti-Stokes Raman spectroscopy (CARS), resonance enhanced Raman scattering (RRS) and spatially offset Raman spectroscopy (SORS). The selection of these variants depends on some inherent factors namely the sample complexity, the type of samples, and the concentrations of the target analytes. CRS is suitable technique in biomedical analysis due to its capability to provide high efficiency, but this technique is not suitable for analysis of analytes with low concentration, therefore, analyst should use other variants capable of amplifying the analyte signals [11]. Table 2 provided the use of Raman spectroscopy for analysis of biomolecules (proteins, lipids, nucleic acids and glucose) in biomedical samples.

\subsection{Analysis of carbohydrate in serum using Raman spectroscopy}

Application of Raman spectroscopy has been explored for glucose analysis in blood serum. Sugar concentration in human diabetic serum has been successfully analyzed using Raman Spectroscopy. Blood serum samples were obtained from normal and diabetic subjects. Raman measurement was performed in the range of $2000-800 \mathrm{~cm}^{-1}$ at $532 \mathrm{~nm}$. Raman spectra of glucose in diabetic mellitus patients appeared at $1168 \mathrm{~cm}^{-1}$ which correspond to the carbohydrate peak. This peak appeared at very low intensity or almost lacking intensity in the normal serum (healthy subjects). The $\mathrm{C}=\mathrm{C}$ (carbon double bond) could be observed from peak appeared at $1650 \mathrm{~cm}^{-1}$. One specific peak at $1463 \mathrm{~cm}^{-1}$ appeared only in blood serum from diabetic subjects that can be used as marker peak of diabetic subject. The glucose peaks at $1168 \mathrm{~cm}^{-1}$ and $1531 \mathrm{~cm}^{-1}$ were plotted against intensity to determine glucose concentration. Eventhough glucose from normal serum still could be detected, the intensity of glucose peaks from diabetic 
Table 2

The application of Raman spectroscopy combined with chemometrics for analysis of biomolecules in biological fluids

\begin{tabular}{|c|c|c|c|c|c|}
\hline Samples & Analytes & Raman condition & Chemometrics & Remarks & References \\
\hline Serum & Glucose & $\begin{array}{l}\text { Diode laser at } 830 \mathrm{~nm} \text { and } \\
25 \mathrm{~mW} \text {; wavenumber of } \\
1800-400 \mathrm{~cm}^{-1}\end{array}$ & PLSR & $\begin{array}{l}\mathrm{LVs}=10 \\
R=0.86 \\
\mathrm{RMSECV}=26.4 \mathrm{mg} / \mathrm{dL}\end{array}$ & Silveira et al. [58] \\
\hline Serum & Glucose & $\begin{array}{l}\text { Diode laser at } 830 \mathrm{~nm}(250 \\
\mathrm{mW}) \text {; wavenumber of } \\
1800-400 \mathrm{~cm}^{-1} \text {; resolution } \\
\text { of } 2 \mathrm{~cm}^{-1}\end{array}$ & PCA & $\begin{array}{l}\text { PCA could discriminate } \\
\text { normal and pathologic } \\
\text { glucose serum. The percent } \\
\text { correct classification was } \\
70 \%\end{array}$ & Borges et al. [10] \\
\hline Serum & $\begin{array}{l}\text { Lipids } \\
\text { (VLDL-TG) }\end{array}$ & $\begin{array}{l}\text { CRS; Nd:YAG } 1064 \mathrm{~nm} \\
\text { laser at power of } 300 \mathrm{~mW} \text {; } \\
\text { wavenumber of } \\
1000-3700 \mathrm{~cm}^{-1} \text { at } \\
\text { resolution of } 4 \mathrm{~cm}^{-1}\end{array}$ & PLS & $\begin{array}{l}Y=0.994 x+0.281 \text { with } \\
R^{2} \text { value of } 0.994\end{array}$ & Oleszko et al. [47] \\
\hline Serum & $\begin{array}{l}\text { Lipids (total } \\
\text { cholesterol, } \\
\text { triglycerides, } \\
\text { HDL, LDL) }\end{array}$ & $\begin{array}{l}\text { Diode laser at } 830 \mathrm{~nm}(250 \\
\mathrm{mW}) ; \text { wavenumber of } \\
1800-400 \mathrm{~cm}^{-1} ; \text { resolution } \\
\text { of } 2 \mathrm{~cm}^{-1}\end{array}$ & PCA & $\begin{array}{l}\text { PCA could discriminate } \\
\text { normal and pathologic lipid } \\
\text { serum. The percent correct } \\
\text { classification was } 77,81, \\
59 \text {, and } 60 \% \text { for total } \\
\text { cholesterol, triglycerides, } \\
\text { HDL, and LDL } \\
\text { respectively). }\end{array}$ & Borges et al. [10] \\
\hline Cell & $\begin{array}{l}\text { Nucleic acid } \\
\text { (RNA) }\end{array}$ & $\begin{array}{l}\text { Diode laser at } 785 \mathrm{~nm} ; \\
\text { spectral range from } \\
1500-500 \mathrm{~cm}^{-1}\end{array}$ & PCA-LDA & $\begin{array}{l}\text { Good accuracy }(89.1 \%) \text { for } \\
\text { cancer subjects and good } \\
\text { accuracy }(92.35 \%) \text { for } \\
\text { healthy subjects }\end{array}$ & Chen et al. [13] \\
\hline Cell & $\begin{array}{l}\text { Nucleic acid } \\
\text { (mi } \\
\text { RNA/micro } \\
\text { RNA) }\end{array}$ & $\begin{array}{l}\text { SERS Raman diode laser at } \\
785 \mathrm{~nm}, \text { spectral range of } \\
1800-400 \mathrm{~cm}^{-1}\end{array}$ & PLSDA & $\begin{array}{l}\text { SERS and PLSDA was } \\
\text { successfully used for } \\
\text { miRNA detection and } \\
\text { classification, } R^{2}=0.967\end{array}$ & Driskell et al. [21] \\
\hline Serum & $\begin{array}{l}\text { Protein } \\
\text { (albumin) }\end{array}$ & $\begin{array}{l}\text { Diode laser at } 785 \mathrm{~nm}(400 \\
\mathrm{mW}) \text {; wavenumber of } \\
3200-2500 \mathrm{~cm}^{-1} \text { and } \\
1146-800 \mathrm{~cm}^{-1} \text { with vector } \\
\text { normalization }\end{array}$ & PLSR & $\begin{array}{l}R^{2}=0.9911 ; \text { RMSECV }= \\
0.64\end{array}$ & Zhao et al. [70] \\
\hline Serum & $\begin{array}{l}\text { Protein } \\
\text { (albumin, Ig } \\
\text { A, Ig G) }\end{array}$ & Diode laser at $785 \mathrm{~nm}$ & PLSR & $\begin{array}{l}R^{2}=0.95 ; 0.94 ; 0.99 \\
\text { (albumin; Ig A; Ig G) } \\
\text { RMSEC = 5.9;0.3; } 0.4 \\
\text { (albumin; Ig A; Ig G) } \\
\text { RMSECV = 7.8;0.5; } 1.2 \\
\text { (albumin; Ig A; Ig G) }\end{array}$ & Artemyev et al. [1] \\
\hline
\end{tabular}

$\overline{P L S R}=$ partial least square regression $; P C A=$ principal component analysis; $P C A-L D A=$ principal component analysislinear discriminant analysis; $P L S-D A=$ partial least square-discriminant analysis.

serum showed very high intensity than normal serum. Therefore, the increasing concentration of glucose could be detected using Raman spectroscopy to differentiate glucose level from serum of normal and diabetic subjects [26].

Quantitative analysis of glucose in human serum has been performed using Raman spectroscopy and chemometrics of PLS regression method. Raman measurement was carried out using diode laser at $830 \mathrm{~nm}$, and each sample was measured in three replicates. The measurement was performed in the range from 1800-400 $\mathrm{cm}^{-1}$. The bands of glucose were observed at $507 \mathrm{~cm}^{-1}$ (skeletal modes of glucose), 
$1065 \mathrm{~cm}^{-1}$ (C-C, C-O, C-H and C-OH modes), and $1128 \mathrm{~cm}^{-1}$ (C-O stretching). Raman spectra were subjected to PLS regression to predict glucose concentration in human serum measured by Raman spectroscopy. The actual value of glucose was obtained from colorimetric method measurement. PLS model was evaluated using $R^{2}$ and RMSECV values. Result of PLS model showed that Raman spectroscopy combined with PLS regression method is a good combination for quantitative analysis of glucose in human serum. PLS could be used to predict glucose concentration in the range of $0-200 \mathrm{mg} / \mathrm{dL}$. Using 10 latent variables (LVs), PLS showed high $R^{2}$ value $(0.86)$ and lower RMSECV value $(26.4 \mathrm{mg} / \mathrm{dL})$ [58].

\subsection{Qualitative and quantitative analysis of lipids using Raman spectroscopy}

Conventional Raman spectroscopy (CRS) has been used for analysis of very low-density lipoproteintriglyceride (VLDL-TG) serum in maternal serum without any sample preparation. The samples were excited using Nd:YAG $1064 \mathrm{~nm}$ laser at power of $300 \mathrm{~mW}$. Raman signal was collected at $1 / \lambda$ of 1000 $3700 \mathrm{~cm}^{-1}$ at resolution of $4 \mathrm{~cm}^{-1}$ for $90 \mathrm{~min}$ and averaged over 2048 accumulations. The multivariate calibration of PLS was applied for prediction the levels of VLDL-TG. Using first derivative Raman spectra at combined $1 / \lambda$ region of $3100-2800$ and $1800-1000 \mathrm{~cm}^{-1}$ with 3 factors, the correlation between actual values ( $x$-axis) of VLDL-TG as determined by triglyceride spectrophotometric assay (Roche Diagnostics) and Raman predicted values ( $y$-axis) was $y=0.994 x+0.281$ with $R^{2}$ value of 0.994 . The prediction models using PLS revealed $R^{2}$ of 0.800 and RMSEP of $0.27 \mathrm{~mol} / \mathrm{L}$. This method has been successfully applied in serum and in ultracentrifugated VLDL fractions from 32 patients with acceptable accuracy as indicated by high $R^{2}$ and precision as indicated by low RMSEP [47].

Quantification of lipid components has been performed using Raman spectroscopy and chemometrics of PLS regression. The lipid components consist of cholesterol, triglycerides, high-density lipoprotein (HDL), and low-density lipoprotein (LDL). Raman spectral data were collected using a near-infrared dispersive Raman spectrometer. The diode laser is $830 \mathrm{~nm}$ with $25 \mathrm{~mW}$. For excitation and collection of Raman spectra, a Raman probe was used and connected to spectrometer. PLS model was carried out using wavenumber of $1800-400 \mathrm{~cm}^{-1}$. The actual concentration of cholesterol, triglycerides, HDL, and LDL were measured using colorimetric methods. Lipid bands could be observed at $1676 \mathrm{~cm}^{-1}(\mathrm{C}=\mathrm{C}$ stretching of cholesterol), $1659 \mathrm{~cm}^{-1}\left(\mathrm{C}=\mathrm{C}\right.$ stretching of unsaturated lipid), $1452 \mathrm{~cm}^{-1}\left(\mathrm{CH}_{3}, \mathrm{CH}_{2}\right.$ bending of lipids), $1269 \mathrm{~cm}^{-1}$ (C=C stretching of saturated lipid), $1085 \mathrm{~cm}^{-1}(\mathrm{C}-\mathrm{O}$ stretching or $\mathrm{C}-\mathrm{C}$ skeletal of unsaturated lipid), and $700 \mathrm{~cm}^{-1}$ (stretching of steroid ring from cholesterol). The $R^{2}$ values obtained from PLS regression were 0.96; 0.98; 0.75; and 0.86, while the RMSEC values were 15.9; 35.4; 17.8; and $24.2 \mathrm{mg} / \mathrm{dL}$ for cholesterol, triglyceride, HDL, and LDL respectively. Whereas the latent variables (LVs) used were 9 for cholesterol and 8 for triglyceride, HDL, and LDL, respectively [58].

Raman spectroscopy has also been used for the quantitative analysis of some compounds in serum including cholesterol, HDL, LDL, triglycerides, and glucose. The concentration was compared to that obtained from enzymatic assay. Chemometrics of PLSR was used to build calibration models. PLSR showed good correlation between Raman and enzymatic assay as shown by the correlation coefficient value for all measured compound was higher than 0.940 . The region used for building PLSR model was in the range of $4000-450 \mathrm{~cm}^{-1}$ and the peaks were normalized to the peak at $1514 \mathrm{~cm}^{-1}$ (peak with highest intensity). The use of Raman was also applied for serum differentiation from normal serum and gastric cancer serum samples. Raman spectra were subjected to chemometrics of partial least squarediscriminant analysis (PLS-DA) for classification. Serum from normal sample could be clearly differentiated with serum from gastric cancer sample by using PLS-DA method [3]. 


\subsection{Analysis of nucleic acid in biomedical fluids using Raman spectroscopy}

Surface-enhanced Raman spectroscopy (SERS) and multivariate analysis of principal component analysis-linear discriminant analysis (PCA-LDA) have been used for analysis of ribonucleic acid (RNA) in serum from normal and colorectal cancer subjects. Mixture of colloidal silver solution and $\mathrm{MgSO}_{4}$ were used as substrate for RNA measurement to enhance the Raman intensity of RNA. Raman measurement was performed using diode laser at $785 \mathrm{~nm}$ in the region of $1500-500 \mathrm{~cm}^{-1}$. Raman spectra from normal subjects were similar with those from colorectal cancer subjects. SERS peaks of RNA appeared at $527 \mathrm{~cm}^{-1}$ (uracil), $573 \mathrm{~cm}^{-1}$ (cytosine, guanine), $678 \mathrm{~cm}^{-1}$ (guanine), 714 and $736 \mathrm{~cm}^{-1}$ (adenine), $859 \mathrm{~cm}^{-1}$ (phosphate group), 1008 and $1033 \mathrm{~cm}^{-1}$ (C-O and C-C stretching), $1240 \mathrm{~cm}^{-1}$ (phosphate asymmetric stretching), $1277 \mathrm{~cm}^{-1}$ (nucleic acid and phosphate), $1316 \mathrm{~cm}^{-1}$ (guanine), and $1391 \mathrm{~cm}^{-1}$ (C-H rocking). However, there were several differences located in several peaks, especially in the peak intensities of RNA between normal and cancer groups. In normal subjects, the peaks at 1391, 1240, 1008, 860 , and $714 \mathrm{~cm}^{-1}$ are higher than in cancer subjects, whereas the peak intensities at 1316, 1277, 1033, and $573 \mathrm{~cm}^{-1}$ are higher in cancer subjects than in normal. Multivariate analysis of PCA-LDA successfully differentiated RNA serum from normal and cancer subjects. RNA serum samples from normal and cancer subjects were clearly separated using LDA analysis. LDA showed good accuracy (89.1\%) for predicting RNA samples from cancer subjects and showed good accuracy $(92.35 \%)$ for predicting RNA samples from normal subjects [13].

Raman spectroscopy in combination with chemometrics of PCA and PLS-DA was used for detection of nucleic acids and protein changes during breast cancer development [45]. Some Raman spectral markers were identified in relation to the specific biomolecule markers such as peak at Raman shift of $689 \mathrm{~cm}^{-1}$ (nucleotide conformation), $788 \mathrm{~cm}^{-1}$ (phosphodiester bands in DNA), $828 \mathrm{~cm}^{-1}$ (tyrosine/protein), 848 and $1663 \mathrm{~cm}^{-1}$ (DNA) have not previously been identified. Principal component analysis-factorial discriminant analysis (PCA-FDA) was successfully used for the classification of Raman spectra related to biomolecules changes in the breast cancer patients, according to different stages of the disease.

Surface-enhanced Raman Spectroscopy (SERS) has been used for analysis of nucleic acids in human infected Hepatitis C (HCV). The Raman spectra of healthy samples were different from those in infected patients with HCV. Several peaks from infected samples were used as markers for nucleic acid in the infected patients. The peaks appeared at $720 \mathrm{~cm}^{-1}$ (adenine), $1077 \mathrm{~cm}^{-1}\left(\mathrm{PO}_{2} \mathrm{RNA}\right.$ stretching), $1678 \mathrm{~cm}^{-1}$ (C-O stretching of RNA), $178 \mathrm{~cm}^{-1}$ (RNA), $1641 \mathrm{~cm}^{-1}$ (amide), $1721 \mathrm{~cm}^{-1}$ (protein stretching), and $1738 \mathrm{~cm}^{-1}$ (C-O ester group in lipids). Principal component analysis has been successfully used for differentiation between normal serum and infected Hepatitis $C$ serum. SERS spectra from normal subjects were clearly separated from SERS spectra obtained from cancer subjects as shown by PCA score plot [19].

\subsection{Protein analysis in biomedical fluids using Raman spectroscopy}

Surface-enhanced Raman spectroscopy (SERS) combined with multivariate analysis of PLSR has been successfully applied to differentiate saliva protein from healthy subject, patient with benign breast tumor, and patient with malignant breast cancer. There are some differences of SERS spectra resulted from normal and tumor group. Some intense peaks appeared at $1684 \mathrm{~cm}^{-1}, 1340 \mathrm{~cm}^{-1}, 1208 \mathrm{~cm}^{-1}$, and $1004 \mathrm{~cm}^{-1}$ in benign and malignant breast tumor group, whereas peaks at $1176 \mathrm{~cm}^{-1}, 1049 \mathrm{~cm}^{-1}$, and $621 \mathrm{~cm}^{-1}$ are higher in normal group. This indicates the changes in saliva proteins either in benign 
or malignant breast tumors. Spectra shifting in saliva protein of malignant breast cancer could also be monitored using SERS. The peak of saliva protein at $1310 \mathrm{~cm}^{-1}$ which appeares in normal subject is shifted to $1318 \mathrm{~cm}^{-1}$ in malignant breast cancer subject. The changes in SERS peak could be used as marker peak for the detection of benign and malignant breast cancer. More exploration was carried out to confirm the spectra from three different groups using multivariate analysis of PLS-DA. Model validation was carried out using leave one out cross validation technique and the score plot of PLS-DA showed clear classification among these three groups (normal, benign tumor, and malignant tumor). PLS-DA showed good diagnostic sensitivity $(75.75 \%, 72.73 \%$, and $74.19 \%)$ and good diagnostic specificity $(87.63 \%$, $78.35 \%$, and $82.47 \%$ ) for normal, benign, and malignant breast tumor subject, respectively [25].

Raman spectroscopy and multivariate analysis of PLS have been used for qualitative and quantitative analysis of albumin and immunoglobulin protein in human serum samples. Raman measurement was performed at $785 \mathrm{~nm}$. Raman spectra of protein fraction could be observed at the band of $1650 \mathrm{~cm}^{-1}$ (vibration of amide I), $1436-1460 \mathrm{~cm}^{-1}\left(\mathrm{CH}_{2}\right.$ deformation), $1300-1343 \mathrm{~cm}^{-1}$ (CH deformation), $1004 \mathrm{~cm}^{-1}$ (phenylalanine), 944 and $890 \mathrm{~cm}^{-1}$ (C-C stretching), and $856 \mathrm{~cm}^{-1}$ (tyrosine) $[18,35,66]$. Raman spectra of albumin, Immunoglobulin A (Ig A), and Immunoglobulin G (Ig G) are similar. However, the intensities of albumin spectra have the highest spectra intensity compared to Ig A and Ig G. Quantitative analysis for determination of albumin, Ig A, and Ig G was performed using PLS regression. PLS models were evaluated using $R^{2}$, RMSEC, and RMSECV value. PLS model showed a good prediction model to determine albumin and immunoglobulin concentrations. The $R^{2}$ values for calibration model were $0.95,0.94$, and 0.99 for albumin, Ig A, and Ig G, respectively. The high values of $R^{2}$ showed good accuracy and predictivity of PLS models. The RMSEC values were 5.9, 0.3 , and 0.4 for albumin, Ig A, and Ig G, respectively whereas the RMSECV values were 7.8, 0.5, and 1.2 for albumin, Ig A, and Ig G, respectively. Lower RMSEC and RMSECV values indicated lower error values in PLS models [1].

The combination of Raman spectroscopy and chemometrics of PLS has been used for protein analysis of human blood fractions. Raman measurement was carried out at $785 \mathrm{~nm}$ and the blood samples were divided into two categories; whole blood and blood plasma. Raman spectra of blood plasma showed several peaks corresponding to protein or protein component signals such as $820 \mathrm{~cm}^{-1}$ (tyrosine), $950 \mathrm{~cm}^{-1}$ (deformation of $\mathrm{C}-\mathrm{H}$ group), 1002 and $1080 \mathrm{~cm}^{-1}$ (phenylalanine), $1160 \mathrm{~cm}^{-1}$ (deformation of CC group), $1250 \mathrm{~cm}^{-1}$ ( $\alpha$-helix of Amide III), $1330 \mathrm{~cm}^{-1}$ (tryptophan), $1450 \mathrm{~cm}^{-1}\left(\mathrm{CH}_{2}\right.$ group), and $1650 \mathrm{~cm}^{-1}$ ( $\beta$-helix of Amide I). Raman spectra of whole blood were similar to blood plasma except in some peaks, namely $570 \mathrm{~cm}^{-1}$ (deformation of $\mathrm{FeO}_{2}$ group), 750 and $670 \mathrm{~cm}^{-1}$ (pyrrole), $1120 \mathrm{~cm}^{-1}$ (C-N group), $1227 \mathrm{~cm}^{-1}$ (deformation of $\mathrm{C}-\mathrm{H}$ group), and $1550 \mathrm{~cm}^{-1}$ (phenylalanine). PLS method was performed to quantify protein either in blood plasma or whole blood. The variable in projection (VIP) analysis from PLS measurement was carried out to identify peaks which have strong contribution to build PLS model. Raman peaks at $570-700 \mathrm{~cm}^{-1}, 1120 \mathrm{~cm}^{-1}, 1550 \mathrm{~cm}^{-1}$ are the most informative peaks in whole blood that correspond to hemoglobin and they are not found at blood plasma spectra. Peaks at $1002 \mathrm{~cm}^{-1}, 1227 \mathrm{~cm}^{-1}, 1440 \mathrm{~cm}^{-1}$, and $1630 \mathrm{~cm}^{-1}$ are the largest VIP value and they can be found both in blood plasma and whole blood that correspond to the peaks of albumin and globulin [41].

Raman spectroscopy has been employed for protein analysis in patient with asthma. Protein could be used as marker molecule to differentiate between normal and pathology condition. In pathology condition, certain protein could be different either in composition or structure from normal condition. Serum samples from asthma patients have been analyzed using Raman spectroscopy to investigate the changes in protein. Result showed that the proteins structures changed as the increasing severity of asthma [53]. Raman spectroscopy has been used for protein analysis in serum. Human blood serum in 
normal health was collected and then measured using Raman at wavelength $780 \mathrm{~nm}$. Protein could be detected using Raman and the signals appeared at several regions. Most of protein signals appeared in the region of $1544 \mathrm{~cm}^{-1}$ and $1648 \mathrm{~cm}^{-1}$, which correspond to the signal of amide II and amide I. Other peak at $904 \mathrm{~cm}^{-1}$ is associated with deformation of $\mathrm{C}-\mathrm{H}$ bond in protein. Proteins have either single bond of $\mathrm{C}-\mathrm{O}$ or double bond of $\mathrm{C}=\mathrm{O}$ that appear at $1740 \mathrm{~cm}^{-1}$ for single bond stretching vibration as well as $1780 \mathrm{~cm}^{-1}$ and $1816 \mathrm{~cm}^{-1}$ for double bond stretching vibration [17].

\section{Conclusion}

FTIR and Raman spectroscopy are non-destructive, fast techniques, and fingerprint techniques for analysis of biomolecules including protein, glucose, lipids, and nucleic acid in biomedical fluid. Combined with chemometrics of multivariate analysis either pattern recognition or regression, FTIR and Raman spectroscopy offer powerful and rapid analysis of biomolecules in biomedical fluids.

\section{Conflict of interest}

The authors have no conflict of interest to report.

\section{References}

[1] D.N. Artemyev, V.P. Zakharov, I.L. Davydkin, J.A. Khristoforova, A.A. Lykina, V.N. Konyukhov and T.P. Kuzmina, Measurement of human serum albumin concentration using Raman spectroscopy setup, Opt. Quant. Electron. 48(6) (2016), 1-8. doi:10.1007/s11082-016-0610-2.

[2] T.C. Baghai, G. Varallo-Bedarida and C. Born, Major depressive disorder is associated with cardiovascular risk factors and low Omega-3 index, J. Clin. Psychiatry 72 (2010), 1242-1247. doi:10.4088/JCP.09m05895blu.

[3] M. Bahreini, A. Hosseinzadegan, A. Rashidi, S.R. Miri, H.R. Mirzaei and P. Hajian, A Raman-based serum constituents' analysis for gastric cancer diagnosis: In vitro study, Talanta 204 (2019), 826-832. doi:10.1016/j.talanta.2019.06.068.

[4] J.M. Baker, S.R. Hussain, L. Lovergne, V. Untereiner and C. Hughes, Developing and understanding biofluid vibrational spectroscopy: A critical review, Chem. Soc. Rev. 45(7) (2015), 1803-1818. doi:10.1039/C5CS00585J.

[5] M.J. Baker, C.S. Hughes and K.A. Hollywood, Biophotonics: Vibrational spectroscopic diagnostics, 2016. doi:10.1088/ 978-1-6817-4071-3.

[6] M.J. Baker, S.R. Hussain, L. Lovergne, V. Untereiner, C. Hughes, R.A. Lukaszewski, G. Thiéfin and G.D. Sockalingum, Developing and understanding biofluid vibrational spectroscopy: A critical review, Chem. Soc. Rev. 45 (2015), 18031818. doi:10.1039/C5CS00585J.

[7] M.J. Baker, J. Trevisan, P. Bassan, R. Bhargava, H.J. Butler, K.M. Dorling, P.R. Fielden, S.W. Fogarty, N.J. Fullwood, K.A. Heys, C. Hughes, P. Lasch, P.L. Martin-Hirsch, B. Obinaju, G.D. Sockalingum, J. Sulé-Suso, R.J. Strong, M.J. Walsh, B.R. Wood, P. Gardner and F.L. Martin, Using Fourier transform IR spectroscopy to analyze biological materials, Nat. Protoc. 9 (2014), 1771-1791. doi:10.1038/nprot.2014.110.

[8] A. Barth, Infrared spectroscopy of proteins, Biochim. Biophys. Acta Bioenerg. 1767 (2007), 1073-1101. doi:10.1016/j. bbabio.2007.06.004.

[9] L. Benezziddine-Boussaidi, G. Cazorla and A.M. Merlin, Validation for quantification of immunoglobulins by Fourier transform infrared spectrometry, Clin. Chem. Lab. Med. 47 (2009), 83-90.

[10] R.D.C.F. Borges, R.S. Navarro, H.E. Giana, F.G. Tavares, A.B. Fernandes and L.S. Junior, Detecting alterations of glucose and lipid components in human serum by near-infrared Raman spectroscopy, Res. Biomed. Eng. 31(2) (2015), 160-168. doi:10.1590/2446-4740.0593.

[11] K. Buckley and G.R. Alan, Applications of Raman spectroscopy in biopharmaceutical manufacturing: A short review, Appl. Spectros. 71(6) (2017), 1085-1116. doi:10.1177/0003702817703270.

[12] A.A. Bunaciu, O.M. Antochi, Ş. Fleschin, V.D. Hoang and H.Y. Aboul-Enein, Vibrational spectroacopy in body fluids analysis, Rev. Roum. Chim. 62 (2017), 465-474. 
[13] Y. Chen, G. Chen, S. Feng, J. Pan, X. Zheng, Y. Su, Y. Chen, Z. Huang, X. Lin, F. Lan, R. Chen and H. Zeng, Label-free serum ribonucleic acid analysis for colorectal cancer detection by surface-enhanced Raman spectroscopy and multivariate analysis, J. Biomed. Opt. 17 (2012), 1-8.

[14] M. Daszykowski and B. Walczak, Use and abuse of chemometrics in chromatography, TrAC - Trends Anal. Chem. 25(11) (2006), 1081-1096. doi:10.1016/j.trac.2006.09.001.

[15] R. Deidda, P.-Y. Sacre, M. Clavaud, L. Coïc, H. Avohou, P. Hubert and E. Ziemons, Vibrational spectroscopy in analysis of pharmaceuticals: Critical review of innovative portable and handheld NIR and Raman spectrophotometers, Trends Anal. Chem. 114 (2019), 251-259. doi:10.1016/j.trac.2019.02.035.

[16] J. Depciuch and M. Parlinska-Wojtan, Comparing dried and liquid blood serum samples of depressed patients: An analysis by Raman and infrared spectroscopy methods, J. Pharm. Biomed. Anal. 150 (2018), 80-86. doi:10.1016/j.jpba.2017.11. 074.

[17] J. Depciuch, M. Sowa-Ku'cma, G. Nowak, D. Dudek, M. Siwek, K. Stycze'n and M. Parli'nska-Wojtan, Phospholipidsprotein balance in affective disorders: Analysis of human blood serum using Raman and FTIR spectroscopy, a pilot study, J. Pharm. Biomed. Anal. 131 (2016), 287-296. doi:10.1016/j.jpba.2016.08.037.

[18] N.C. Dingari, G.L. Horowitz, J.W. Kang, R.R. Dasari and I. Barman, Raman spectroscopy provides a powerful diagnostic tool for accurate determination of albumin glycation, PLOS ONE 7(2) (2012), e32406. doi:10.1371/journal.pone.0032406.

[19] A. Ditta, H. Nawaz, T. Mahmood, M.I. Majeed, M. Tahir, N. Rashid, M. Muddassar, A.A. Al-Saadi and H.J. Byrne, Principal components analysis of Raman spectral data for screening of Hepatitis C infection, Spectrochimica Acta Part A: Mol. Biomol. Spectrosc. 221 (2019), 117113.

[20] G.I. Dovbeshko, N.Y. Gridina, E.B. Kruglova and O.P. Pashchuk, FTIR spectroscopy studies of nucleic acid damage, Talanta 53 (2000), 233-246. doi:10.1016/S0039-9140(00)00462-8.

[21] J.D. Driskell, A.G. Seto, L.P. Jones, S. Jokela, R.A. Dluhy, Y.P. Zhao and R.A. Tripp, Rapid microRNA (miRNA) detection and classification via surface-enhanced Raman spectroscopy (SERS), Biosensors and Bioelectronics 24 (2008), 917-922. doi:10.1016/j.bios.2008.07.060.

[22] I. Elsohaby, J.T. Mcclure, C.B. Riley, J. Bryanton, K. Bigsby and A. Shaw, Centrifugal ultrafiltration of human serum for improving immunoglobulin A quantification using attenuated total reflectance infrared spectroscopy, J. Pharm. Biomed. Anal. 150 (2018), 413-419. doi:10.1016/j.jpba.2017.12.031.

[23] K. Ember, M.A. Hoeve, S.L. McAughtrie, M.S. Bergholt, B.J. Dwyer, M.M. Stevens, K. Faulds, S.J. Forbes and C.J. Campbell, Raman spectroscopy and regenerative medicine: A review, NPJ Reg. e Med. 2 (2017), 1-12. doi:10.1038/ s41536-017-0014-3.

[24] A.M.K. Enejder, T.G. Scecina, J. Oh, M. Hunter, W.C. Shih, S. Sasic, G.L. Horowitz and M.S. Feld, Raman spectroscopy for noninvasive glucose measurements, J. Biomed. Opt. 10 (2005), 31114. doi:10.1117/1.1920212.

[25] S. Feng, S. Huang, D. Lin, G. Chen, Y. Xu, Y. Li, Z. Huang, J. Pan, R. Chen and H. Zeng, Surface-enhanced Raman spectroscopy of saliva proteins for the noninvasive differentiation of benign and malignant breas tumors, Int. J. Nanomedicine. 10 (2015), 537-547. doi:10.2147/IJN.S71811.

[26] S. Firdous, M. Nawaz, M. Ahmed, S. Anwar, A. Rehman, R. Rashid and A. Mahmood, Measurement of diabetic sugar concentration in human blood using Raman spectroscopy, Laser Physics 22 (2012), 1-5. doi:10.1134/S1054660X11190054.

[27] K. Gajjar, Diagnostic segregation of human brain tumours using Fourier-transform infrared and/or Raman spectroscopy coupled with discriminant analysis, Anal. Methods. 5 (2013), 89-102. doi:10.1039/C2AY25544H.

[28] S.E. Glassford, B. Byrne and S.G. Kazarian, Recent applications of ATR FTIR spectroscopy and imaging to proteins, Biochim. Biophys. Acta. 1834 (2013), 2849-2858. doi:10.1016/j.bbapap.2013.07.015.

[29] S. Gok, O.Z. Aydin, Y.S. Sural, F. Zorlu, U. Bayol and F. Severcan, Bladder cancer diagnosis from bladder wash by Fourier transform infrared spectroscopy as a novel test for tumor recurrence, J. Biophotonics. (2016), 1-9.

[30] E. Goormaghtigh, J.M. Ruysschaert and V. Raussens, Evaluation of the information content in infrared spectra for protein secondary structure determination, Biophys. J. 90 (2006), 2946-2957. doi:10.1529/biophysj.105.072017.

[31] P. Goralski, Interactions between cholesterol and triacylglycerols in carbon tetrachloride: Calorimetric and spectroscopic studies, Thermochim. Acta 274 (1996), 45-52. doi:10.1016/0040-6031(95)02677-0.

[32] D. Granato, P. Putnik, D.B. Kovačević, J.S. Santos, V. Calado, R.S. Rocha, A.G. Cruz, B. Da-Jarvis, O.Y. Rodionova and A. Pomerantsev, Trends in chemometrics: Food authentication, microbiology, and effects of processing, Compr. Rev. Food Sci. Food Saf. 17(3) (2018), 663-677. doi:10.1111/1541-4337.12341.

[33] T.E. Jessen, A.T. Höskuldsson, P.J. Bjerrum, H. Verder, L. Sørensen, P.S. Bratholm, B. Christensen, L.S. Jensen and M.A.B. Jensen, Simultaneous determination of glucose, triglycerides, urea, cholesterol, albumin and total protein in human plasma by Fourier transform infrared spectroscopy: Direct clinical biochemistry without reagents, Clin. Biochem. 47 (2014), 1306-1312. doi:10.1016/j.clinbiochem.2014.05.064.

[34] J.G. Kelly, P.L. Martin-Hirsch and F.L. Martin, Discrimination of base differences in oligonucleotides using mid-infrared spectroscopy and multivariate analysis, Anal. Chem. 81 (2009), 5314-5319. doi:10.1021/ac900546m. 
[35] R.P. Kengne-Momo, P. Daniel, F. Lagarde, Y.L. Jeyachandran, J.F. Pilard, M.J. Durand-Thouand and G. Thouand, Protein interactions investigated by the Raman spectroscopy for biosensor applications, Int. J. Spectrosc. 2012 (2012), 462901. doi:10.1155/2012/462901.

[36] J. Kong and S. Yu, Fourier transform infrared spectroscopic analysis of protein secondary structures, Acta Biochim. Biophys. Sin. 39 (2007), 549-559. doi:10.1111/j.1745-7270.2007.00320.x.

[37] Y. Lai, Y. Ni and S. Kokot, Discrimination of Rhizoma Corydalis from two sources by near-infrared spectroscopy supported by the wavelet transform and least-squares support vector machine methods, Vib. Spectrosc. 56(2) (2011), 154-160. doi:10.1016/j.vibspec.2011.01.007.

[38] L.B. Leala, M.S. Nogueirab, R.A. Canevari and L.F.C.S. Carvalho, Vibration spectroscopy and body biofluids: Literature review for clinical applications, Photodiag. Photodyn. Ther. 24 (2018), 237-244. doi:10.1016/j.pdpdt.2018.09.008.

[39] K.M.G. Lima, K.B. Gajjar, P.L. Martin-Hirsch and F.L. Martin, Segregation of ovarian cancer stage exploiting spectral biomarkers derived from blood plasma or serum analysis: ATR-FTIR spectroscopy coupled with variable selection methods, Biotechnol. Prog. 31(3) (2015), 832-839. doi:10.1002/btpr.2084.

[40] K.Z. Liu, R.A. Shaw, A.M. Thomas, C. Dembinski and H.H. Mantsch, Reagent-free, simultaneous determination of serum cholesterol in HDL and LDL by infrared spectroscopy, Clin. Chem. 48(3) (2002), 499-506.

[41] A.A. Lykina, D.N. Artemyev, I.A. Bratchenko, Y.A. Khristoforova, O.O. Myakinin, T.P. Kuzmina, I.L. Davydkin and V.P. Zakharov, Raman spectra analysis of human blood protein fractions using the projection on latent structures method, Computer Opt. Nanophotonics 1 (2017), 64-68. doi:10.18287/1613-0073-2017-1900-64-68.

[42] M. Maes, A. Christophe, J. Delanghe, H. Neels and H.Y. Meltzer, Lowered omega-3 polyunsaturated fatty acids in serum phospholipidss and cholesteryl esters od depressed patients, Psychiatry Res. 85 (1999), 275-291. doi:10.1016/S01651781(99)00014-1.

[43] A.L. Mitchell, K.B. Gajjar, G. Theophilou, F.L. Martin and P.L. Martin-Hirsch, Vibrational spectroscopy of biofluids for disease screening or diagnosis: Translation from the laboratory to a clinical setting, J. Biophotonics. 7 (2014), 153-165. doi:10.1002/jbio.201400018.

[44] J. Moros, S. Garrigues and M. de la Guardia, Vibrational spectroscopy provides a green tool for multi-component analysis, Trend Anal. Chem. 29 (2010), 578-591. doi:10.1016/j.trac.2009.12.012.

[45] H.F. Nargis, H. Nawaz, A. Ditta, T. Mahmood, M.I. Majeed, N. Rashid, M. Muddassar, H.N. Bhatti, M. Saleem, K. Jilani, F. Bonnier and H.J. Byrne, Raman spectroscopy of blood plasma samples from breast cancer patients at different stages, Spectrochimica Acta Part A: Mol. Biomol. Spectrosc. 222 (2019), 117210. doi:10.1016/j.saa.2019.117210.

[46] C.A. Nunes, M.P. Freitas, A.C.M. Pinheiro and S.C. Bastos, Chemoface: A novel free user-friendly interface for chemometrics, J. Braz. Chem. Soc. 23(11) (2012), 2003-2010. doi:10.1590/S0103-50532012005000073.

[47] A. Oleszko, J. Hartwich, A. Wójtowicz, M. Gąsior-Głogowska, H. Huras and M. Komorowska, Comparison of FTIR-ATR and Raman spectroscopy in determination of VLDL triglycerides in blood serum with PLS regression, Spectrochim. Acta Part A: Mol. Biomol. Spectros. 183 (2017), 239-246. doi:10.1016/j.saa.2017.04.020.

[48] D. Perez-Guaita, J. Ventura-Gayete, C. Pérez-Rambla, M. Sancho-Andreu, S. Garrigues and M. de la Guardia, Protein determination in serum and whole blood by attenuated total reflectance infrared spectroscopy, Anal. Bioanal. Chem. 404 (2012), 649-656. doi:10.1007/s00216-012-6030-7.

[49] D. Perez-Guaita, J. Ventura-Gayete, C. Pérez-Rambla, M. Sancho-Andreu, S. Garrigues and M. De la Guardia, Evaluation of infrared spectroscopy as a screening tool for serum analysis. Impact of the nature of samples included in the calibration set, Microchem. J. 106 (2013), 202-211. doi:10.1016/j.microc.2012.06.016.

[50] J. Pichardo-Molina, C. Frausto-Reyes, O. Barbosa-García, R. Huerta-Franco, J. González-Trujillo, C. Ramírez-Alvarado, G. Gutiérrez-Juárez and C. Medina-Gutiérrez, Raman spectroscopy and multivariate analysis of serum samples from breast cancer patients, Lasers Med. Sci. 22 (2007), 229-236. doi:10.1007/s10103-006-0432-8.

[51] O.Y. Rodionova and A.L. Pomerantsev, Chemometrics: Achievements and prospects, Russ. Chem. Rev. 75(4) (2006), 271-287. doi:10.1070/RC2006v075n04ABEH003599.

[52] A. Rohman, A. Windarsih, S. Riyanto Sudjadi, S.A.S. Ahmad, A.S. Rosman and F.M. Yusoff, Fourier transform infrared spectroscopy combined with multivariate calibrations for the authentication of avicado oil, Int. J. Food Prop. 19 (2016), 680-687. doi:10.1080/10942912.2015.1039029.

[53] A. Sahu, K. Dalal, S. Naglot, P. Aggarwal and C.M. Krishna, Serum based diagnosis of asthma using Raman spectroscopy: An early phase pilot study, PloS ONE 8 (2013), 1-13.

[54] W.B. Sanders, Clinical Guide to Laboratory Tests, 4th edn, N.W. Tietz, ed., WB Saunders Company, Philadelphia, 2006, pp. 444-451.

[55] G. Sankari, E. Krishnamoorthy, S. Jayakumaran, S. Gunasekaran, V. Vishnu Priya, S. Subramaniam, S. Subramaniam and S.K. Mohan, Analysis of serum immunoglobulins using Fourier transform infrared spectral measurements, Biol. Med. 2 (2010), 42-48.

[56] K. Sato, M. Seimiya, Y. Kodera, A. Kitamura and F. Nomura, Application of Fourier-transform infrared (FT-IR) spectroscopy for simple and easy determination of chylomicron-triglyceride and very low density lipoprotein-triglyceride, Clin. Chim. Acta. 411 (2010), 285-290. doi:10.1016/j.cca.2009.11.026. 
[57] R.A. Shaw, S. Low-Ying, M. Leroux and H.H. Mantsch, Toward reagent-free clinical analysis: Quantitation of urine urea, creatinine, and total protein from the mid-infrared spectra of dried urine films, Clin. Chem. 46 (2000), 1493-1495.

[58] L. Silveira, R.D.C.F. Borges, R.S. Navarro, H.E. Giana, R.A. Zângaro, M.T.T. Pacheco and A.B. Fernandes, Quantifying glucose and lipids components in human serum by Raman spectroscopy and multivariate statistics, Las. Med. Sci. 32 (2017), 787-795. doi:10.1007/s10103-017-2173-2.

[59] I. Singh, P. Juneja, B. Kaur and P. Kumar, Pharmaceutical applications of chemometric techniques, ISRN Anal. Chem. 2013 (2013), 1-13.

[60] K. Spalding, F. Bonnier, C. Bruno, H. Blasco, R. Board, I.B. Bretagne, H.J. Byrne, H.J. Butler, I. Chourpa, P. Radhakrishnan and M.J. Baker, Enabling quantification of protein concentration in human serum biopsies using attenuated total reflectance - Fourier transform infrared (ATR-FTIR) spectroscopy, Vibr. Spec. 99 (2018), 50-58. doi:10.1016/j.vibspec. 2018.08.019.

[61] K. Spalding, F. Bonnier, C. Bruno, H. Blasco and R.E. Board, Enabling quantification of protein concentration in human serum biopsies using attenuated total reflectance - Fourier transform infrared (ATR-FTIR) spectroscopy, Vib spectrosc 99 (2018), 50-58. doi:10.1016/j.vibspec.2018.08.019.

[62] R.R. Sultana, S.N. Zafarullah and H.H. Kirubamani, Utility of FTIR spectroscopic analysis os saliva of diabetic pregnant woman in each trimester, Indian J. S. Technol. 8 (2011), 967-970.

[63] W.K. Surewicz, H.H. Mantsch and D. Chapman, Determination of protein secondary structure by Fourier-transform infrared spectroscopy - a critical assessment, Biochemistry 32 (1993), 389-394. doi:10.1021/bi00053a001.

[64] H. Tiemeier, H.R. van Tuijl and A. Hofman, Plasma fatty acid composition and depression are associated in the elderly: The rotterdam study, Am. J. Clin. Nutr. 78 (2003), 40-46. doi:10.1093/ajcn/78.1.40.

[65] A.W. Wahlefeld, Triglycerides determination after enzymatic hydrolysis, in: Methods of Enzymatic Analysis Methods of Enzymatic Analysis, H.U. Bergmeyer, ed., 2nd English edn, Academic Press Inc., New York, NY, 1974, p. 1831. doi:10. 1016/B978-0-12-091304-6.50036-7.

[66] J. Wang, D. Lin, J. Lin, Y. Yu, Z. Huang, Y. Chen, J. Lin, S. Feng, B. Li, N. Liu and R. Chen, Label-free detection of serum proteins using surface-enhanced Raman spectroscopy for colorectal cancer screening, J. Biomed. Opt. 19(8) (2014), 087003. doi:10.1117/1.JBO.19.8.087003.

[67] D.R. Whelan, K.R. Bambery, L. Puskar, D. McNaughton and B.R. Wood, Quantification of DNA in simple eukaryotic cells using Fourier transform infrared spectroscopy, J. Biophotonics. (2012), 1-10.

[68] J. Xie, H. Zhang, J. Li and F. Ca, Window subtracted wave band selection method for the FTIR/ATR spectrum analysis, Prog. Electromag. Res. 68 (2018), 53-59. doi:10.2528/PIERM17110705.

[69] C.R. Yonzon, C.L. Haynes, X. Zhang, J.T.J. Walsh and R.P.A. Van-Duyne, A glucose biosensor based on surface-enhanced Raman scattering: Improved partition layer, temporal stability, reversibility, and resistance to serum protein interference, Anal. Chem. 76 (2004), 78-85. doi:10.1021/ac035134k.

[70] Y. Zhao, N. Ji, X. Li, J. Hou, M. Li, Y. Yang, P. Tian, X. Sun, X. Xiao and L. Yin, Study on a noninvasive method for rapid screening human serum albumin injectables by Raman spectroscopy, J. Innov. Health Sci. 10(1) (2016), 1-9. 